\title{
Market Linkage of Indian Stock Market with Select Stock Markets
}

\author{
Ram Raj, G*. and A. Marcus \\ Loyola College, Chennai, India \\ "Corresponding author: rams2595@gmail.com
}

\begin{abstract}
This paper examines the market linkage and volatility estimation of Indian stock market with selected stock markets in the world by using various econometric models from the period of $1^{\text {st }}$ April 2000 to $31^{\text {st }}$ March 2018. The result suggests that Indian market positively correlated with the other selected stock markets. Indian stock market has significant influence with two out of five markets in the short run. In the long run relationship, there is no linkage between markets. However, there exists bidirectional causality in the markets. Also, there is market price volatility, and the clustering effect was found in all the major markets. From the study, it is apparent that the Indian stock market has an impact on the other stock market, in the short run. Hence, investors have the opportunity to reap the benefits of the portfolio diversification by gaining knowledge from market integration.

JEL Classification: C01, C22, F32, G11, G15.
\end{abstract}

Keywords: Correlation, ADF, Granger Causality, Stock Market Integration, Volatility

With the promising growth rate and enormous human capital, India is one of the promising nations with the robust capital market. The globalisation movement started in the year 1991 through economic reformation, has opened the floodgates of Indian corporate to international investment avenues. Over recent years, capital market regulators encourage the domestic corporates to get listed in the worldwide stock markets. The policy reformation had developed a linkage between Indian corporates to approach the global markets for their capital requirements. Extensive options provided by the foreign portfolios, global depository receipts have shifted the level playing ground to the Indian corporates and the domestic investors. Though the risk of the international crisis has an impact on their return, still a divergence in the market enables them to dilute the volatility with the assured return. High volatile of market leads to market disruption where securities were not priced equally and not function well. Therefore, this paper aims to examine the market linkage and volatile pattern estimation between the Indian stock market compared with selected international Stock markets.

\section{REVIEW OF LITERATURE}

A wide range of studies has been conducted to understand the market linkage and the existence of volatility among the stock markets. Some of them are referred to as the review of the literature. (Grubel, 1968) had described the international market linkage, very first time, in the history of stock market integration. Followed by (Agmon, 1972) (Hamao, 1990) who had pointed out that there were very low market linkage and no relationship between developed markets. Their aim was to experiment that the international portfolio diversification as beneficial to investors or not. Later they identified that the correlation analysis was not the only tool to analyse the market movement.

(Eun, 1989) Used the co-integration model to study the co-movement of the market linkage. Whereas (Johansen, 1990) found a single common trend for co-integration in stock markets of the USA, Japan, 
England, Germany particularly by using quarterly data. (Kasa, 1992) First applied multivariate cointegration method to examine the common stochastic trend in the financial market and drivers of the co-integration system. According to him a gain from diversification are possible in the short term but not in the long term, as it's not cointegrated. (Arshanapalli \& Doukas, 1993) (Arshanapalli, 1995) Revealed the co-integration between the Asian market with the US market before the period of 1987. He found that these markets were regionally integrated but not at international level. (Mishra, 2002) found that there was a short-run relationship between NASDAQ and BSE market but had no long-run co-integration effect.

(Cheung \& $\mathrm{Ng}$, 1992) used GARCH method to examine the properties of stock return in Tokyo and New York and found that there would be a consistent pattern in the time series data. (Wong, Agarwal, \& Du, 2004) studied the unidirectional Granger causality between US, UK, Japan and Indian market. (Chen, 2006) evaluated the bilateral relationship between three major stock markets like India, the US and China. (Menon, Subha, \& Sagaran, 2009) noticed that there was no cointegration between NSE and NASDAQ, but strong co-integration between NSE and Singapore market. (Sharma, Singh, \& Singh, 2011) Examined the interlinkage between the Indian market and Brazil, Chinese markets, and found the influence in Brazil and the Indian market. For (Singh, 2011) there was unidirectional Granger causality from the US to the Indian market. (Palamalai, M, \& Devakumar, 2013) understood that the long-run relationship between Asian Pacific countries and found that it helped the investors to gain more benefits in the term of market risk.

In a recent study, (Juneja, 2017) explored the positive dynamic linkage between the BRIC countries and the Indian market. Thus, the referred review reveals certain aspects of the existing body of research on the existence of co-integration of stock markets. This study carried to examine the market linkage and volatility pattern estimation in Indian stock market with selected stock markets.

\section{Objective}

- To examine the stock market linkage between India and Major five stock markets;
- To investigate the cause and effect relationship between stock markets;

- To analyse the volatile and impact of Indian market return in major stock exchanges.

\section{RESEARCH METHODOLOGY}

This study is entirely based on secondary data and its empirical study. All the data used for this study was acquired from the official website of respective stock markets such as India (Bombay Stock Exchange) and a few other information from yahoo finance. The daily market data were collected for the period between 1 April 2000 and 31 March 2018 (4624 daily observations). (Engle, 1982) Suggested that at least eight years of data should be used to estimate GARCH models. For this study major six stock markets indices were chosen, a market which is followed in table 1 .

Table 1: Stock Market, Countries, Their Index Code and Index Detail

\begin{tabular}{|c|c|c|c|}
\hline Stock Market & Country & $\begin{array}{l}\text { Index } \\
\text { Code }\end{array}$ & Index Detail \\
\hline $\begin{array}{l}\text { Bombay Stock } \\
\text { Exchange }\end{array}$ & India & SENSEX & Sensitivity Index \\
\hline $\begin{array}{l}\text { European Stock } \\
\text { Exchange }\end{array}$ & Europe & ENX & Euro Next \\
\hline $\begin{array}{l}\text { Hong Kong Stock } \\
\text { market }\end{array}$ & $\begin{array}{l}\text { Hong } \\
\text { Kong }\end{array}$ & HSI & Hang Seng Index \\
\hline $\begin{array}{l}\text { American Stock } \\
\text { Market }\end{array}$ & $\begin{array}{l}\text { United } \\
\text { States }\end{array}$ & S\&P 500 & $\begin{array}{l}\text { Standard \& Poor } \\
500\end{array}$ \\
\hline $\begin{array}{l}\text { Shanghai Stock } \\
\text { Exchange }\end{array}$ & China & SSE & $\begin{array}{l}\text { SSE composite } \\
\text { index }\end{array}$ \\
\hline $\begin{array}{l}\text { Tokyo Stock } \\
\text { Exchange }\end{array}$ & Japan & TOPIX & $\begin{array}{l}\text { Tokyo Stock } \\
\text { Price Index }\end{array}$ \\
\hline
\end{tabular}

Source: Yahoo finance.

The market return was calculated as per the following equation (1)

$$
R_{t}=\left(P_{t}\right)-\left(P_{t-1}\right) /\left(P_{t-1}\right)
$$

Where $R_{t}$ is the daily market index at time t. $P_{t}$ denotes the market index at time period $t$, and $P_{t-1}$ denotes the market index in the selected market at time period $t-1$. For analysis the data "Eviews 10" statistical software package was used to perform econometric analysis such as Augmented DickeyFuller (ADF) test (Stationarity), correlation test (short-term relationship), Granger causality (cause 
Table 2: Summary Statistics of The Market Returns

\begin{tabular}{ccccccc}
\hline & BSE & ENX & HSI & S\&P 500 & SSE & TPX \\
\hline MEAN & 15106.54 & 4326.455 & 18873.74 & 1451.799 & 2420.806 & 13405.15 \\
MEDIAN & 15995.46 & 4277.610 & 20136.88 & 1314.350 & 2225.602 & 12826.22 \\
MAX & 36283.25 & 6922.330 & 33154.12 & 2872.870 & 6092.057 & 24124.15 \\
MIN & 2600.120 & 2403.040 & 8409.010 & 676.5300 & 1011.499 & 7054.980 \\
STD. DEV & 9003.994 & 896.6987 & 5394.461 & 455.1562 & 915.3226 & 3831.912 \\
SKEWNESS & 0.248501 & 0.400551 & -0.075906 & 0.971091 & 0.974439 & 0.465676 \\
KURTOSIS & 1.977634 & 2.526884 & 2.159513 & 3.136108 & 4.174850 & 2.187987 \\
JARQUE-BERA & 248.9719 & 166.7729 & 140.5436 & 730.3219 & 997.7039 & 294.1596 \\
(Prob) & $(0.0000)$ & $(0.0000)$ & $(0.0000)$ & $(0.0000)$ & $(0.0000)$ & $(0.0000)$ \\
\hline
\end{tabular}

Source: Author's Calculation.

and effect relationship), cointegration test (longrun relationship) and GARCH model (estimate volatility) was applied.

\section{EMPIRICAL RESULTS}

\section{Descriptive Statistics}

The descriptive statistics of stock market index returns are presented in Table 2.

Table 2 shows the summary of the statistics of the market index return of all six stock markets. As per the table, the highest mean value is the Hong Kong stock market and the lowest in the American stock market. Among those six stock markets, India's Bombay stock exchange had more standard deviation; it means more volatility in the market and very high-risk market. S\&P 500 had very low standard deviation which means very less risk compared with other markets. The skewness for the returns for all the stock markets are positive (nonasymmetric); only Hong Kong marker is negative which means it is asymmetric. The Jarque-Bera test for normality portrays a significance level of 5\%, indicating the rejection of the null hypothesis that means the time series data of market indices are not normally distributed.

\section{Analysis of Correlation Test}

The correlation coefficient is used to measure the extent of the strength and direction of the association between the indices and stock returns in different countries. The analysis of Karl person's correlation is presented in the table 3 .

Table 3, Karl person's correlation among the BSE and other indices show that all the stock markets are positively correlated that means all the stock exchanges have a short run relationship. Among those exchanges, the Hong Kong market has highly associated with the Indian market almost 90\%, whereas Europe stock market is least correlated. So, the Indian market does have the linkage virtually with every stock market.

Table 3: Karl person's correlation test

\begin{tabular}{ccccccc}
\hline & BSE & ENX & HSI & S\&P 500 & SSE & TPX \\
\hline BSE & 1.0000 & 0.1648 & 0.9078 & 0.8498 & 0.6535 & 0.5909 \\
\hline
\end{tabular}

Source: Author's Calculation.

\section{Augmented Dickey-Fuller Unit Root Test}

Before examining the market linkage among the Indian stock market and selected stock markets, it is essential to check the univariate properties of the data series are non-stationary, or they contain a unit root. For that, ADF unit root test is employed, which was developed by Dickey-Fuller. A time series is said to be stationary that means, the variance of the series does not symmetrically differ over time. Nonstationary data will lead to incorrect concluding. (Dickey \& Fuller, 1979). Unit root was calculated as per the following equation (2).

$$
\Delta Y_{t}=\beta_{1}+\beta_{2} t+\delta Y_{t-1}+\sum_{i=1}^{m} \alpha i \Delta Y_{t-i}+\varepsilon_{t}
$$

Where $\delta Y_{t-1}$ is the first difference operation, $\beta_{1^{\prime}} \beta_{2} t$ are coefficient to be estimated. $\delta=0, \varepsilon_{t}$ is white noise error term, if the estimated slope of coefficient in this regression $\delta$ (hypothesis) is zero or not. If it is zero, then $Y_{t}$ is nonstationary. The optimal lag length was taken with the Akaike Information Criterion (AIC) and maximum lag was put to 36 (Gujarati, 
2009). The ADF null hypothesis is there as unit root in the time series, whereas, the alternative is - there is no unit root and it is stationary. It observed and presented in table 4 .

Table 4: Augmented Dickey-Fuller Unit Root Test

\begin{tabular}{ccccc}
\hline & \multicolumn{2}{c}{ At level } & \multicolumn{2}{c}{$\mathbf{1}^{\text {st }}$ Difference } \\
\cline { 2 - 5 } & t-Statistic & Prob & t-Statistic & Prob \\
\hline BSE & 0.011560 & 0.9586 & -63.24618 & 0.0001 \\
ENX & -2.559700 & 0.1016 & -70.81904 & 0.0001 \\
HSI & -1.083922 & 0.7243 & -69.05869 & 0.0001 \\
S\&P 500 & 0.688765 & 0.9920 & -52.23863 & 0.0001 \\
SSE & -1.839817 & 0.3614 & -30.87954 & 0.0000 \\
TPX & -1.628682 & 0.4678 & -69.57530 & 0.0001 \\
\hline
\end{tabular}

Source: Author's Calculation.

Table 4 presented the $t$ statistics and prob values of all the stock markets at both level and first level. From the table, all the probability value of 'At level' is not significant that means the data series is not stationary, it has a unit root. In the first difference, all the index probability value is less than $5 \%$, that means it rejects the null hypothesis to accept the alternative, so the data becomes stationary after the first difference in ADF test.

\section{Analysis of Granger Causality test}

The Granger causality test is conducted to investigate the direction of causality between the Indian market and other major stock markets. This test checks that whether the today's Indian market return is influenced by previous day return of any other markets. This test is applied only to stationary time series data. Granger causality was calculated as per following formula (3 \& 4) (Gujarati, 2009).

$$
\begin{aligned}
& \Delta Y_{t}=\sum_{i=1}^{m} \alpha_{i} Y_{t-i}+\sum_{j=1}^{m} \beta_{j} X_{t-j}+\lambda_{1} t+\varepsilon_{1} t \\
& \Delta X_{t}=\sum_{i=1}^{m} \gamma_{i} X_{t-i}+\sum_{j=1}^{m} \delta_{j} Y_{t-j}+\lambda_{2} t+\varepsilon_{2} t
\end{aligned}
$$

Where, $\Delta$ is the difference operator, $T_{t-i}$ and $X_{t-j}$ are represent as the lagged value of $Y_{t}$ and $X_{t} \cdot \varepsilon_{1}$ and $\varepsilon_{2}$ are error terms assumed white noise. The lag length was picked by using Akaike Information Criteria (AIC). The Granger Causality Test results are showed in Table 5.
Table 5: Granger Causality Test

\begin{tabular}{ccc}
\hline Null Hypothesis & F-Statistic & Prob \\
\hline ENX does not Granger Cause BSE & 41.8082 & $1 . \mathrm{E}-18^{*}$ \\
BSE does not Granger Cause ENX & 1.07549 & 0.3412 \\
HSI does not Granger Cause BSE & 4.54184 & $0.0107^{*}$ \\
BSE does not Granger Cause HSI & 50.6749 & $2 . \mathrm{E}-22^{*}$ \\
S\&P 500 does not Granger Cause BSE & 113.719 & $6 . \mathrm{E}-49^{*}$ \\
BSE does not Granger Cause S\&P 500 & 0.87431 & 0.4172 \\
SSE does not Granger Cause BSE & 5.23761 & $0.0053^{*}$ \\
BSE does not Granger Cause SSE & 15.9175 & $1 . \mathrm{E}-07^{*}$ \\
TPX does not Granger Cause BSE & 0.26593 & 0.7665 \\
BSE does not Granger Cause TPX & 66.9920 & $2 . \mathrm{E}-29^{*}$ \\
\hline
\end{tabular}

Source: Author's Calculation.

Table 5, expresses that Granger Causality Test results in which shows that the European market has an impact on the Indian market. In the same way, the American market also causes the unidirectional effect. Hong Kong and Shanghai markets have an effect both the directions, so it's called bidirectional impact. That means any news of the Indian stock market will have an impact on both the market and vice versa.

\section{Results of Cointegration Test}

(Johansen, 1990) Cointegration test is the most widely used method in examining the long-run equilibrium relationship of the different time series or integration in the financial market. Following table 6 shows the cointegration relation between Indian market with other selected stock markets.

Table 6: Johansen Cointegration Test

\begin{tabular}{cccccc}
\hline & $\begin{array}{c}\text { Hypothesised } \\
\text { No. of CE(s) }\end{array}$ & $\begin{array}{c}\text { Trace } \\
\text { Statistic }\end{array}$ & prob & $\begin{array}{c}\text { Max-Eigen } \\
\text { Statistic }\end{array}$ & prob \\
\hline ENX & None & 7.557820 & 0.5138 & 7.534769 & 0.4280 \\
& At most 1 & 0.023051 & 0.4280 & 0.023051 & 0.8792 \\
HSI & None & 11.29454 & 0.1940 & 11.29401 & 0.1401 \\
& At most 1 & 0.001439 & 0.9682 & 0.001439 & 0.9682 \\
S\&P & None & 6.594793 & 0.6252 & 6.436309 & 0.5579 \\
500 & At most 1 & 0.158485 & 0.6906 & 0.158485 & 0.6906 \\
SSE & None & 5.713288 & 0.7291 & 5.661154 & 0.6570 \\
& At most 1 & 0.052123 & 0.8194 & 0.052134 & 0.8194 \\
TPX & None & 11.21602 & 0.1986 & 11.20215 & 0.1444 \\
& At most 1 & 0.013875 & 0.9061 & 0.013875 & 0.9061 \\
\hline
\end{tabular}

Source: Author's Calculation. 
The result of the cointegration test, trace and maxeigenvalues are checked at 5\% significant level. Here the null hypothesis is that 'these series are not integrated with the Indian market'. From the table 6 , all the markets index probability values are more than $5 \%$ significant level, so it shows the data fail to reject the null hypothesis that means there is no long-run relationship between Indian stock market and other markets.

\section{Estimation of volatility}

Garch model is useful in analysing the financial time series such as market indices. A distinguishing feature of these models is that the error variance may be correlated over time because of the phenomenon of volatility clustering. The Arch model was developed by (Engle, 1982) and Garch model was initially proposed by (Bollerslev, 1986) the simplest model GARCH $(1,1)$ can be written as per equation 5.

$$
\sigma_{t}^{2}=\alpha_{0}+\sum_{i=1}^{p} \alpha_{i} \varepsilon_{t-i}^{2}+\sum_{j=1}^{q} \beta_{j} \sigma_{t-j}^{2}+\lambda
$$

Where $\sigma_{t}^{2}$ is the variance for the time t. $\alpha_{i}$ and $\beta_{j}$ are coefficients. $\varepsilon_{t-i}$ is the lagged residual from the mean equation and, $\sigma_{t-j}{ }^{2}$ is the lagged variance from the period $t-j . \lambda$ is the coefficient measuring the impact of Bombay stock exchange return on the volatility of other stock market indices. Estimated GARCH coefficient and prob value for returns are presented in Table 7.

Table 7: Volatility Estimation

\begin{tabular}{cccc}
\hline & ARCH & GARCH & BSE \\
\hline ENX & 0.072240 & 0.912368 & -0.456258 \\
& $(0.0000)$ & $(0.0000)$ & $(0.0000)$ \\
HSI & 0.050348 & 0.948401 & -3.432338 \\
& $(0.0000)$ & $(0.0000)$ & $(0.0018)$ \\
S\&P 500 & 0.077669 & 0.906560 & -0.029407 \\
& $(0.0000)$ & $(0.0000)$ & $(0.0000)$ \\
SSE & 0.066288 & 0.933496 & -0.010950 \\
& $(0.0000)$ & $(0.0000)$ & $(0.5155)$ \\
TPX & 0.01077 & 0.909809 & -5.484601 \\
& $(0.0000)$ & $(0.0000)$ & $(0.0000)$ \\
\hline
\end{tabular}

Source: Author's Calculation.

From the table (7) ARCH and GARCH coefficient were all significant at 5 per cent level, which means there is an autoregressive effect in all the stock markets. So, the future is influenced by past movement of market return. Garch effect is also significant that means there is a strong volatility clustering effect was found in the data. The impact of BSE market return in other stock market was significant at 5\% level in all the market, but it has a negative value, and so there is an adverse impact in the markets.

\section{Findings}

From this study, it is found that in the short run period all the markets are integrated but not in the long run period. The reason being, almost all the investors, are anxious to speculate the shares and not holding for a long period. Also, in a long period, a lot of major economic variables such as GDP rate, countries economic policies, political vagaries, interest rate, employment rate, ecological imbalance, and technological advancement are some of the factors to makes the markets to perform independently. So, the investors are very sensitive in a short period, but in the long period, they are trained to predict the market movement precisely. Thus, the short run variation of the advanced nations like Europe and India has an effect on the Indian stock market. Therefore, the developing countries are dependent on the price movement of the stocks of developed nations.

\section{CONCLUSION}

This study was intended to examine the market linkage and volatile estimation of Indian stock market with other selected stock markets, globally by using various econometric models for the period from 1 April 2000 to 31 March 2018. It is found that the Hong Kong stock market is highly correlated with the Indian stock market. The data considered for the study was non-stationary, but while checking ADF at first level, it was stationary. The Granger Casualty test suggests that there is bidirectional causality between Hong Kong and Shanghai stock markets with the Indian market. Johansen Cointegration test revealed that there is no long-run relationship between any other markets with the Indian market. The volatility effect and clustering effect were found in the market indices. Thus, there is a negative influence made by the select stock market on the Indian stock. This reveals that the investors are abreast with the information on the 
interlinkage of markets that enable to diversity their investment portfolios among different countries in different securities.

\section{REFERENCES}

Agmon, T. 1972. The relations among equity markets: a study of share price co-movements in the United States, United Kingdom, Germany and Japan. The Journal of Finance, 27(4): 839-855.

Arshanapalli, B. \& Doukas, J. 1993. International stock market linkages: Evidence from the pre-and post-October 1987 period. Journal of Banking E Finance, 17(1): 193-208.

Arshanapalli, B., Doukas, J. \& Lang, L.H. 1995. Pre and postOctober 1987 stock market linkages between US and Asian markets. Pacific-Basin Finance Journal, 3(1): 57-73.

Bollerslev, T. 1986. Generalised Autoregressive Conditional Heteroskedasticity. Journal of Econometrics, pp. 307-327.

Cheung, Y.W. \& Ng, L.K. 1992. Stock price dynamics and firm size: An empirical investigation. The Journal of Finance, 47(5): 1985-1997.

Dickey, D.A. \& Fuller, W.A. 1979. Distribution of the Estimators for Autoregressive Time Series With a Unit Root. Journal of the American Statistical Association, pp. 427-431.

Ding, Z., Granger, C.W. \& Engle, R.F. 1993. A long memory property of stock market returns and a new model. Journal of Empirical Finance, pp. 83-106.

Engle, R. 2001. GARCH 101: The use of ARCH/GARCH models in applied econometrics. The Journal of Economic Perspectives, 15(4): 157-168.
Engle, R.F. 1982. Autoregressive Conditional Heteroscedasticity with Estimates of the Variance of United Kingdom Inflation. The Econometric Society, pp. 987-1007.

Eun, C.S. \& Shim, S. 1989. International transmission of stock market movements. Journal of financial and Quantitative Analysis, 24(2): 241-256.

Grubel, H.G. 1968. Internationally diversified portfolios: welfare gains and capital flows. The American Economic Review, 58(5): 1299-1314.

Gujarati, D.N. 2009. Basic Econometrics. Delhi: Tata McGrawHill Education.

Hamao, Y., Masulis, R.W. \& Ng, V. 1990. Correlations in price changes and volatility across international stock markets. The Review of Financial Studies, 3(2): 281-307.

Johansen, S. \& Juselius, K. 1990. Maximum likelihood estimation and inference on cointegration - with applications to the demand for money. Oxford Bulletin of Economics and statistics, 52(2): 169-210.

Juneja, S. 2017. Dynamic Linkage between the Brazilian, Russian, Indian \& Chinese Stock Markets. International Journal of Research in Engineering, It and Social Sciences, 64-69.

Kasa, K. 1992. Common stochastic trends in international stock markets. Journal of Monetary Economics, 29(1): 95-124.

Palamalai, S. \& Devakumar, C. 2013. Stock market linkages in emerging Asia-Pacific markets. SAGE Open, 3(4): 2158244013514060

Rajiv Menon, N., Subha, M.V. \& Sagaran, S. 2009. Cointegration of Indian stock markets with other leading stock markets. Studies in Economics and Finance, 26(2): 87-94. 